\title{
Spatial Patterning of Material Culture Remains and Animal Bone at an Early 18th Century Caddo Site in East Texas
}

Timothy K. Perttula

Heritage Research Center, Stephen F. Austin State University

Bo Nelson

Heritage Research Center, Stephen F. Austin State University

Mark Walters

Heritage Research Center, Stephen F. Austin State University

Follow this and additional works at: https://scholarworks.sfasu.edu/ita

Part of the American Material Culture Commons, Archaeological Anthropology Commons, Environmental Studies Commons, Other American Studies Commons, Other Arts and Humanities Commons, Other History of Art, Architecture, and Archaeology Commons, and the United States History Commons

Tell us how this article helped you.

This Article is brought to you for free and open access by the Center for Regional Heritage Research at SFA ScholarWorks. It has been accepted for inclusion in Index of Texas Archaeology: Open Access Gray Literature from the Lone Star State by an authorized editor of SFA ScholarWorks. For more information, please contact cdsscholarworks@sfasu.edu. 
Spatial Patterning of Material Culture Remains and Animal Bone at an Early 18th Century Caddo Site in East Texas

\section{Creative Commons License}

\section{(c) (1) \&}

This work is licensed under a Creative Commons Attribution-NonCommercial 4.0 International License 


\title{
Spatial Patterning of Material Culture Remains and Animal Bone at an EARly $18^{\mathrm{Th}}$ Century Caddo Site in EAST TEXAS
}

\author{
Timothy K. Perttula, Bo Nelson, and Mark Walters
}

\author{
Introduction
}

The J. T. King site (41NA15) is an early $18^{\text {th }}$ century Caddo habitation site on King Creek, a tributary to the Angelina River (Figure 1). It is situated on the northern route of El Camino Real de los Tejas, about $5 \mathrm{~km}$ east of the Camino Real's crossing of the Angelina River. This is an area where Historic Caddo sites are relatively common, and there are sites generally contemporaneous with the J. T. King site both north and south some distance along King Creek (Middlebrook 2007; Perttula et al. 2011a, 2011b).

Archaeogeophysical and archaeological investigations were conducted intermittingly at the J. T. King site since May 2008, following the relocation of the site by Tom Middlebrook in 2006. The archaeogeophysical work was led by Dr. Chester P. Walker, and covered a 6.1 acre area of the site (see Walker and Perttula [2010, 2011], and Walker et al. [2009] for details on the methods and results of the magnetometer survey). During that work, a considerable number of geophysical anomalies were defined, including 10 circular to sub-round anomalies (Anomalies A-J) that range from 3.7 to $12.5 \mathrm{~m}$ in diameter (Figure 2). A number of them have smaller anomalies situated in or near their centers that are likely central hearths or large post holes (i.e., center posts) inside Caddo structures (Walker and Perttula 2010:315).

The archaeological investigations at the J. T. King site have included the excavation of numerous shovel tests ( $\mathrm{n}=59)$ and a total of $171 \times 1 \mathrm{~m}$ units (Figure 3). The main goals of the shovel testing and had excavation units were to (a) establish the specific spatial distribution and density of Historic Caddo artifacts and plant and animal remains across the site as a whole, (b) establish their distribution in relationship to previously defined geophysical anomalies, especially those that have been inferred to represent structural anomalies, and (c) archaeologically ground-truth certain geophysical anomalies-particularly anomalies that may represent domestic structures (or portions of them)-using carefully placed suites of closely-spaced shovel tests across specific areas of anomalies, as well as hand-excavated units situated atop or within the boundaries of these anomalies.

Our focus in this paper is to examine the distribution of material culture remains and animal bones at the J. T. King site. The spatial patterning and density of various kinds of artifacts, including European trade goods, ceramic sherds, chipped stone tools, lithic debris, and animal bones on the J. T. King site should provide a singular archaeological view of the distribution of material culture remains that cluster and are concentrated in different parts of the site. This variability in spatial patterning can then provide hints as to the intra-site organization of the Historic Caddo community that occupied the site (probably only for ca. 20 years, see discussion in Good [1982] above the longevity of Caddo wood structures), especially the location of midden areas and possible outdoor activity areas. This information, when viewed in conjunction with the locations of different kinds and sizes of geophysical anomalies identified on the site, including an area suspected to represent a possible courtyard, and identified cultural features that have been exposed in hand excavations (Walker and Perttula 2011:40-43), leads to definitive insights into the overall spatial character of the Historic Caddo community at the J. T. King site. 


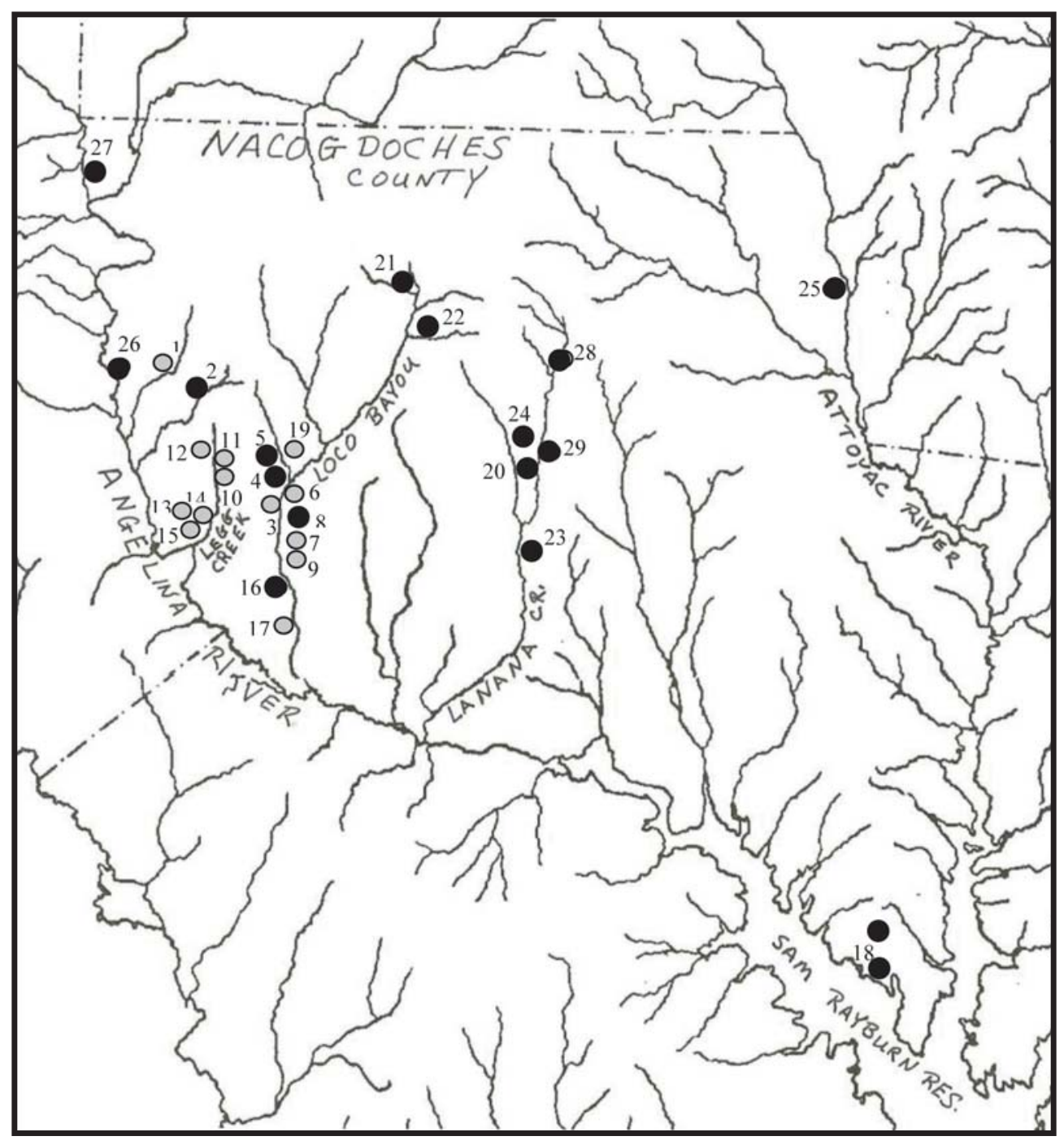

Figure 1. Known and possible Historic Caddo sites in Nacogdoches County, Texas (from Middlebrook 2007:Figure 1). Black circles are locations of Historic Caddo sites; gray circles are location of possible Historic Caddo sites: 1, Dorsey (41NA6); 2, J. T. King (41NA15); 3, 41NA18; 4, Mayhew (41NA21); 5, Iron Rock (41NA22); 6, Loco Bottom (41NA23); 7, 41NA26; 8, Deshazo (41NA27); 9, Perkins (41NA29); 10, 41NA33; 11; Chayah (41NA44); 12, 41NA47; 13, 41NA53; 14, Cecil Sparks (41NA54); 15, 41NA55; 16, Henry M. (41NA60); 17, 41NA65; 18, 41NA67; 19, Dick Shipp (41NA111); 20, 41NA113; 21, Loco Fork (41NA187); 22, Stephens (41NA202); 23, Spradley (41NA206); 24, Guadalupe Pilar (41NA223); 25, Joe Little; 26, A. L. Self; 27, W. T. Williamson; 28, Appleby Bead; 29, Nacogdoches East Bead. 


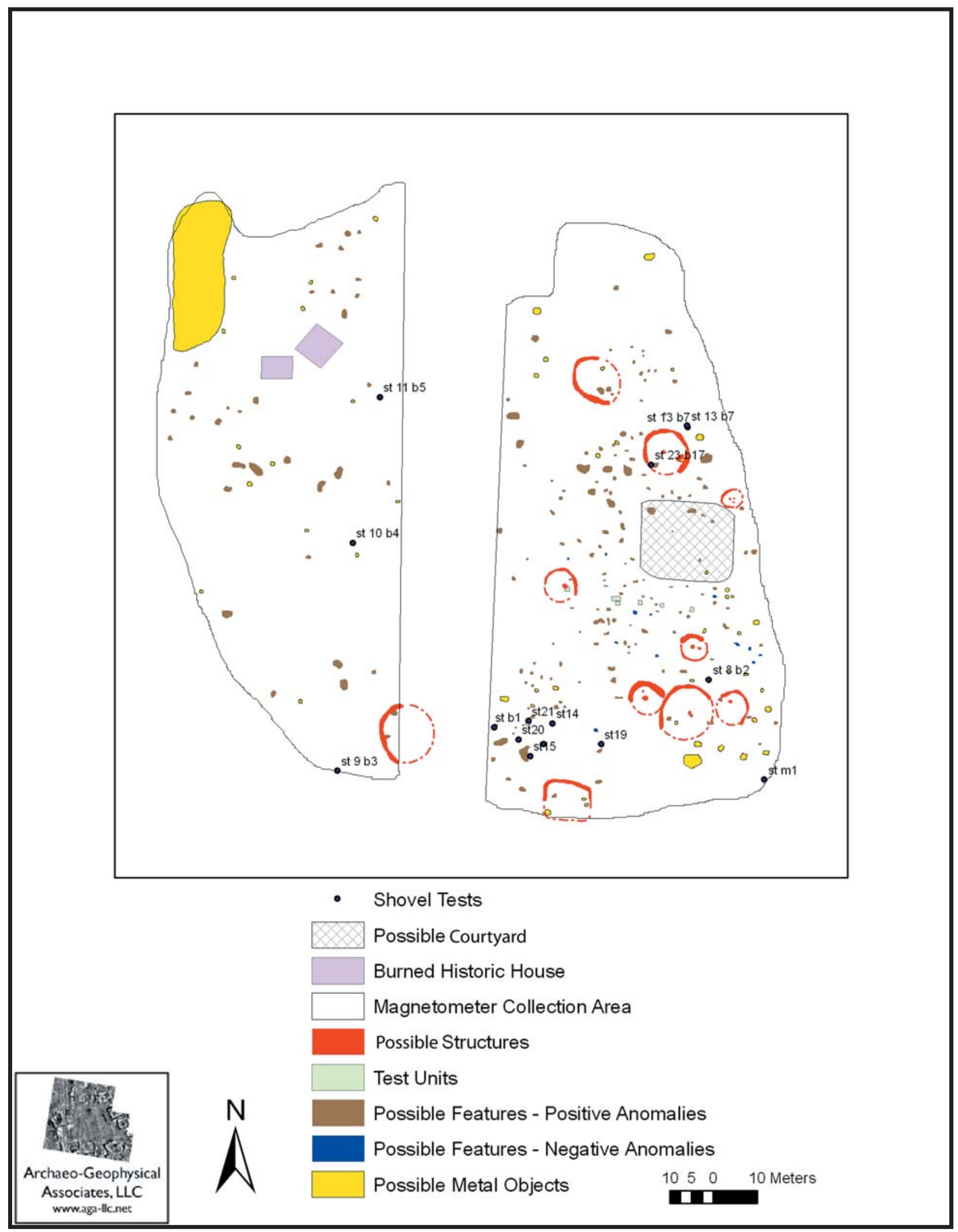

Figure 2. Preliminary interpretive map of the J. T. King site based on the magnetometer findings. 


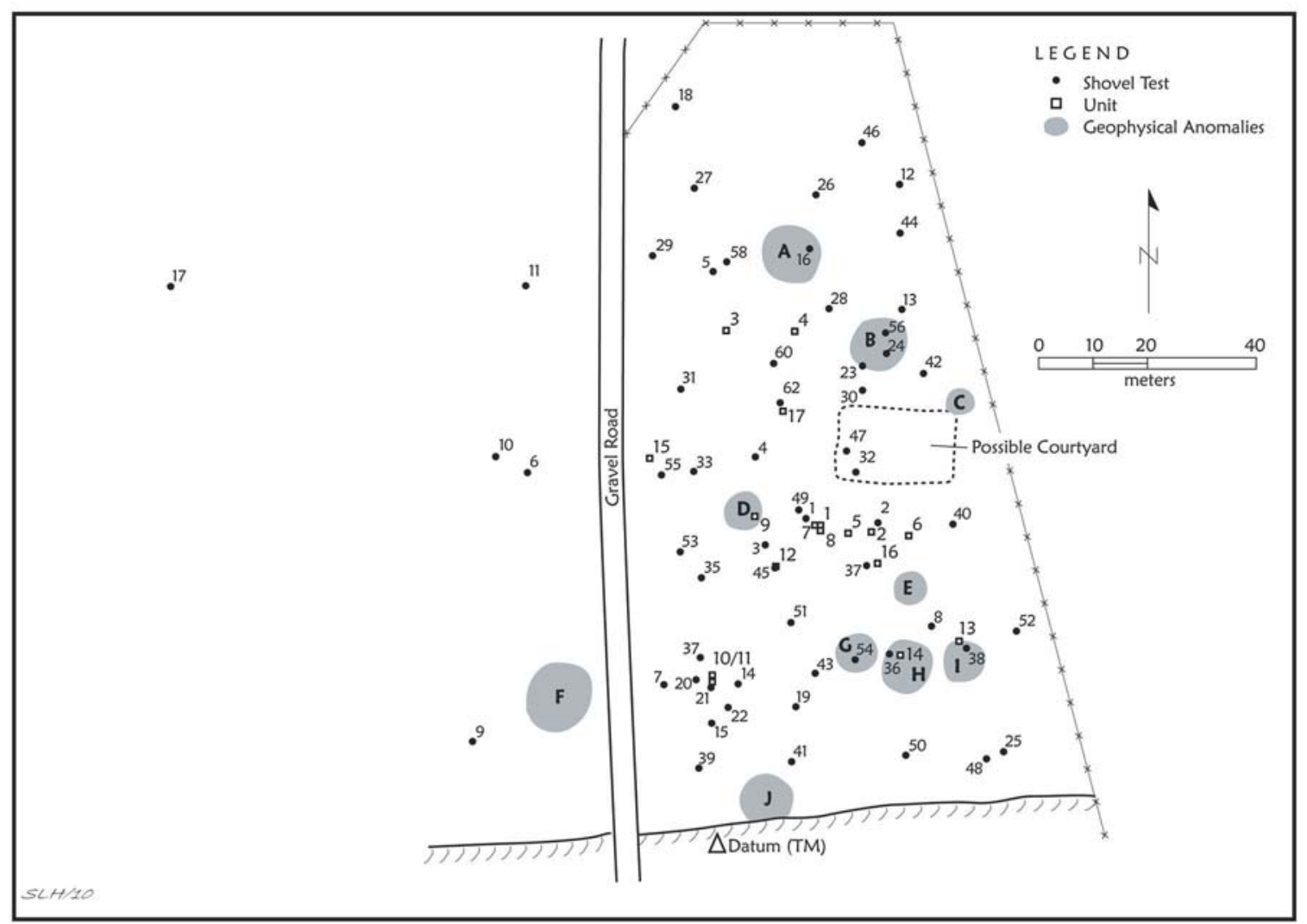

Figure 3. Map of the J. T. King site showing the locations of shovel tests, hand excavation units, and primary geophysical anomalies (A-J).

\section{Spatial Patterning of Material Culture Remains}

Including the results of earlier archaeological investigations as well as the last round of work in 2010, Historic European trade goods are rare $(n=4)$ in habitation contexts at the J. T. King site (Figure 4). These goods include a glass bead found east of geophysical anomaly D, a lead ball between geophysical anomalies F and G, a cupreous or copper-base tinkler cone fragment from Unit 5, midway between geophysical structural anomalies D and E, and a second cupreous or copper-base tinkler cone fragment from the same area as the lead ball. None of these trade goods were found in feature contexts, nor were they within the larger geophysical anomalies of structure-size. The concentration of features in these same areas, however (see Walker and Perttula 2011:Figure 21), suggest that there may have been structures-perhaps ramadas, arbors, or elevated work areas-in these areas as well as outdoor work areas.

The shovel testing defined moderate (greater than 80 sherds per $\mathrm{m}^{2}$ ) and high densities (greater than 135 sherds per $\mathrm{m}^{2}$ ) of ceramic sherds in several areas of the site (Figure 5). The largest area, and including shovel tests with moderate to high densities of sherds, is a ca. $40 \times 40 \mathrm{~m}$ area in the south central part of the site; this area has numerous positive geophysical anomalies (see Figure 2), and is situated between geophysical structural anomalies D, G-H to the east, and geophysical anomalies F and J in the southern part of the site. In the main, this density of sherds appears to mark an outdoor work area, where vessels were used and broken, rather than an accumulation of sherds from inside habitation structural features. There are apparent midden deposits in the western part of this sherd distribution area. A second area of moderate sherd density is specifically noted from shovel tests within and outside the boundaries of geophysical structural anomaly I (Figure 5); this may represent a smaller accumulation of sherd from the occupants of this structural anomaly. The last area of moderate sherd density is from a single shovel test about 20 m east of geophysical structural anomaly A (Figure 5), and these sherds are also not apparently from a structural context. 


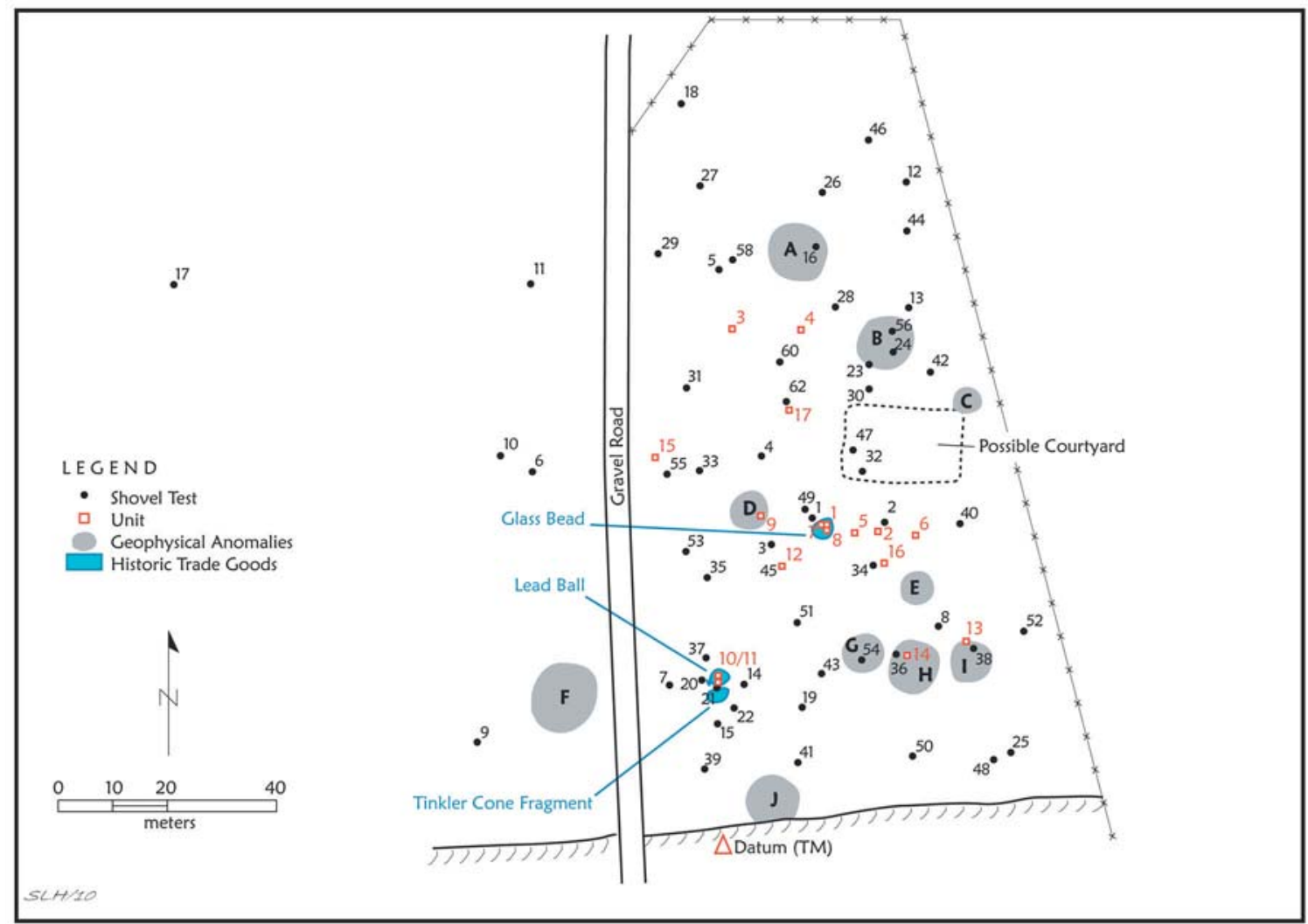

Figure 4. Distribution of Historic European trade goods at the J. T. King site.

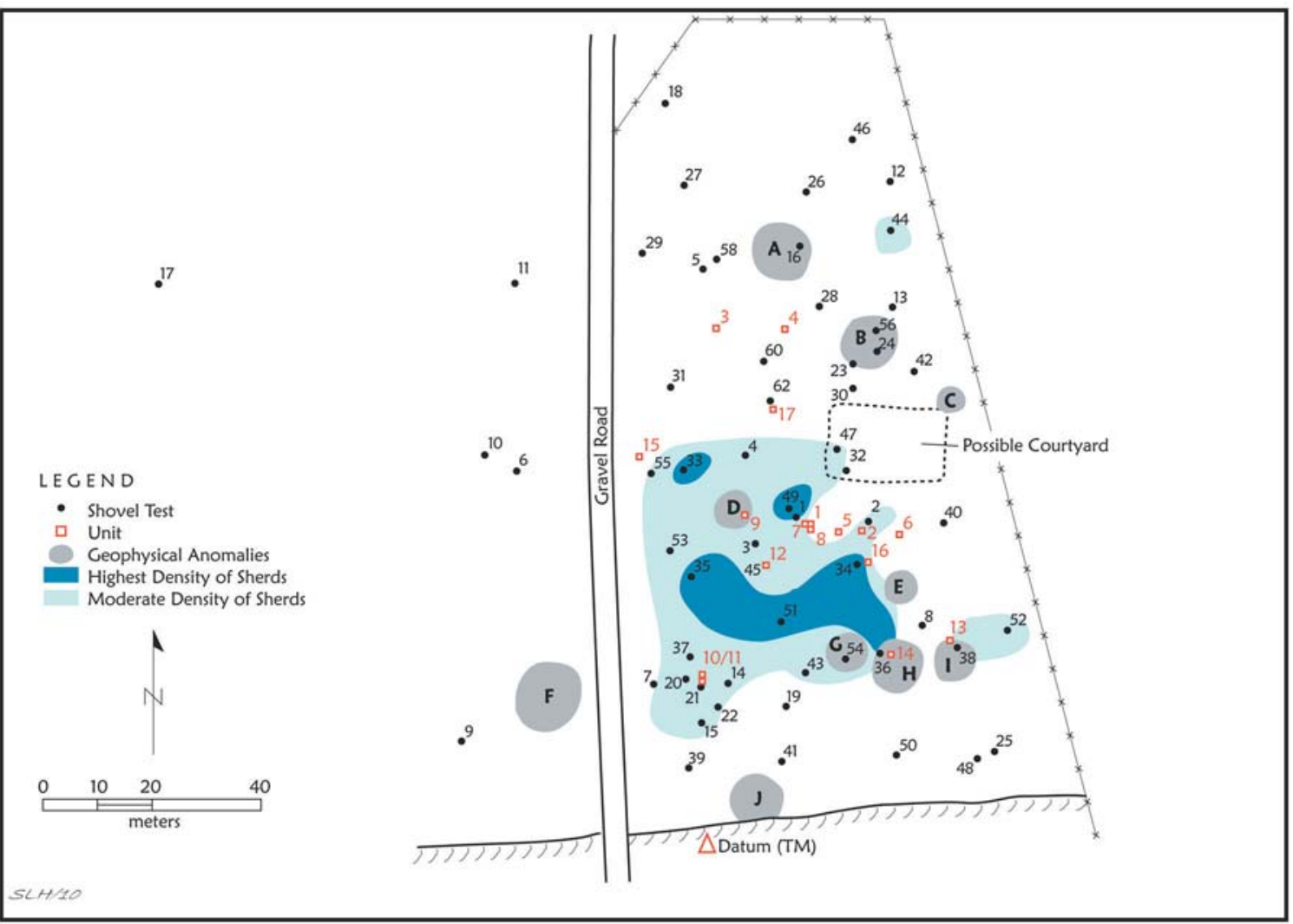

Figure 5. Distribution of moderate density and highest density of ceramic sherds in the shovel testing at the J. T. King site. 
It may be significant that there are not moderate or high densities of sherds in the area identified by Walker and Perttula $(2010,2011)$ as a possible courtyard (see Figure 2). The absence of significant densities of artifacts or animal bones (see below) in the possible courtyard area may reflect its limited use for mundane domestic activities, although it may also be a product of the fact that few shovel tests were excavated there. However, most shovel tests to the immediate north or south of the possible courtyard also do not have many artifacts.

Stone tools (both chipped and ground stone) from the shovel tests are concentrated in only one area of the J. T. King site: shovel tests immediately south of and from within geophysical structural anomaly B (Figure 6), north a short distance from the possible courtyard. It is notable that these stone tools were not discarded in the one large and apparent outdoor work area south and west of the courtyard-where the ceramic sherds are concentrated, as are animal bones and midden deposits-but in a restricted area around geophysical anomaly $\mathrm{B}$, suggesting this area was a specific focus of stone tool use and discard of broken tools.

Evidence of chipped stone tool manufacture at the J. T. King site is marked by the distribution of pieces of lithic debris; the overall density (see Walker and Perttula 2011:Tables 1 and 2) of lithic debris suggests that chipped stone tool manufacture was not a common activity at the site, with only 39 pieces recovered in the 2010 shovel testing ( 1.15 pieces per shovel test) and 130 pieces from Units 11-17 (18.6 pieces per $1 \mathrm{x} 1 \mathrm{~m}$ unit). There are two areas at the site with higher densities (ca. 24-32 pieces per $\mathrm{m}^{2}$ ) of lithic debris, one between the possible courtyard and geophysical structure anomaly D (Figure 7), in an apparent outdoor work and trash disposal area (see Figure 5), and the other at the southern end of the site. This latter area, about 40 × $20 \mathrm{~m}$ in size, partially overlaps with geophysical structural anomalies $\mathrm{H}$ and I. Consequently, it may mark the chipped stone knapping activities of the occupants of geophysical structural anomalies G-I.

Burned and unburned animal bone was also relatively abundant in a number of shovel tests, particularly in non-geophysical structural anomaly areas (Figure 8). This would seem to indicate that the distribution of bone may mark the locations of midden deposits or more concentrated trash disposal areas. The highest densities (ca. 60 bones per $\mathrm{m}^{2}$ ) of bone occurs between geophysical structural anomaly $\mathrm{D}$ and geophysical structural anomalies E and G. The area of ST 55 (and Unit 15), northwest of geophysical structural anomaly D, also has a substantial density of animal bones in the archaeological deposits.

Of the 59 shovel tests that have been excavated at the J. T. King site between 2008-2010, four of them (ST 24, 36, 38, and 54) have animal bone from within geophysical structural anomalies (i.e., B, G-I), while another 24 shovel tests outside of structural anomalies have animal bone. As previously mentioned, most of the latter are in the area between geophysical structural anomalies D and G, or are in an area about $10 \mathrm{~m}$ south of geophysical structural anomalies $\mathrm{H}$ and I (see Figure 8). This clearly suggests that animal bone was discarded as trash in outdoor contexts, such as a midden or work area, but not far from domestic structures. 


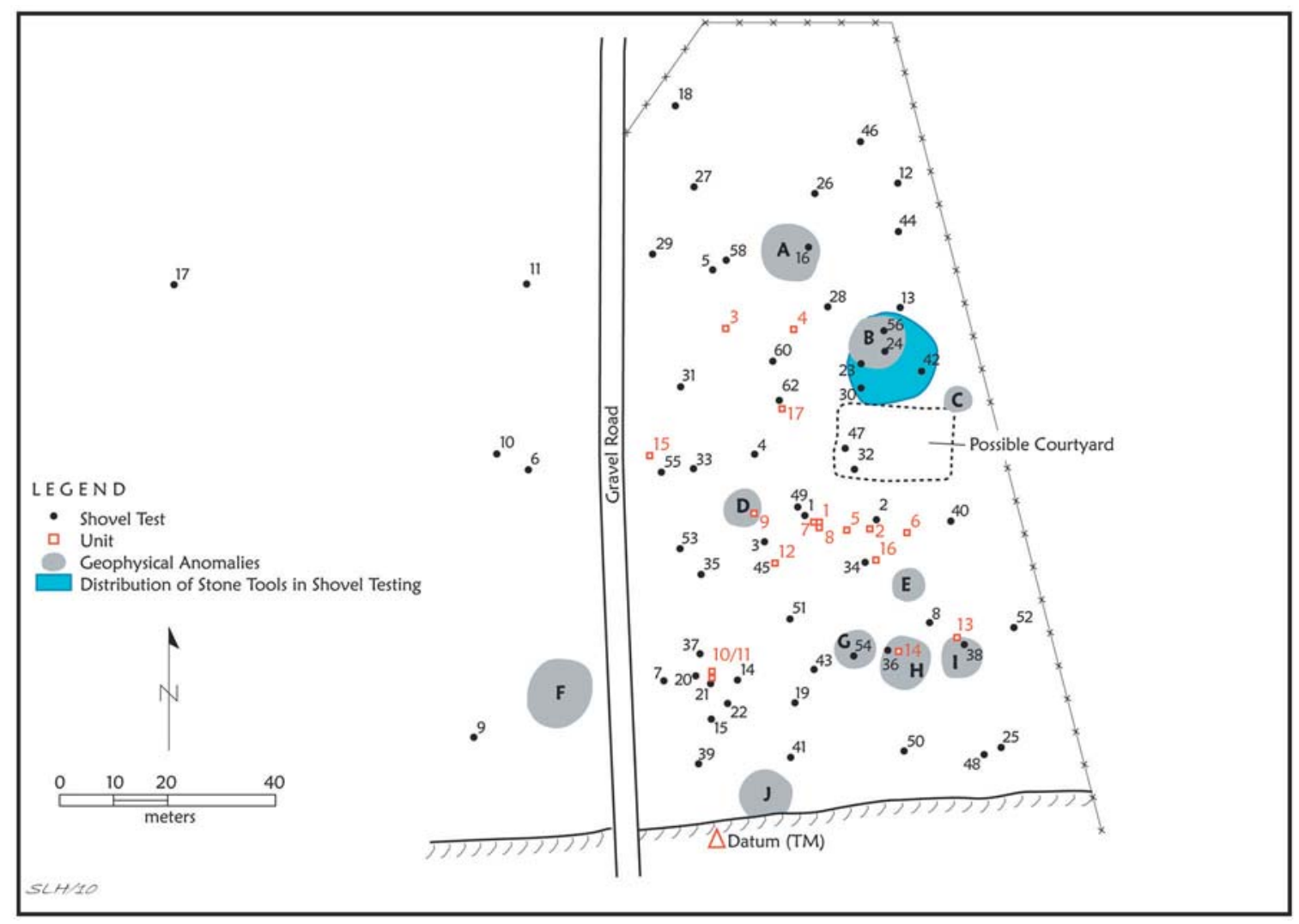

Figure 6. Distribution of stone tools in shovel testing.

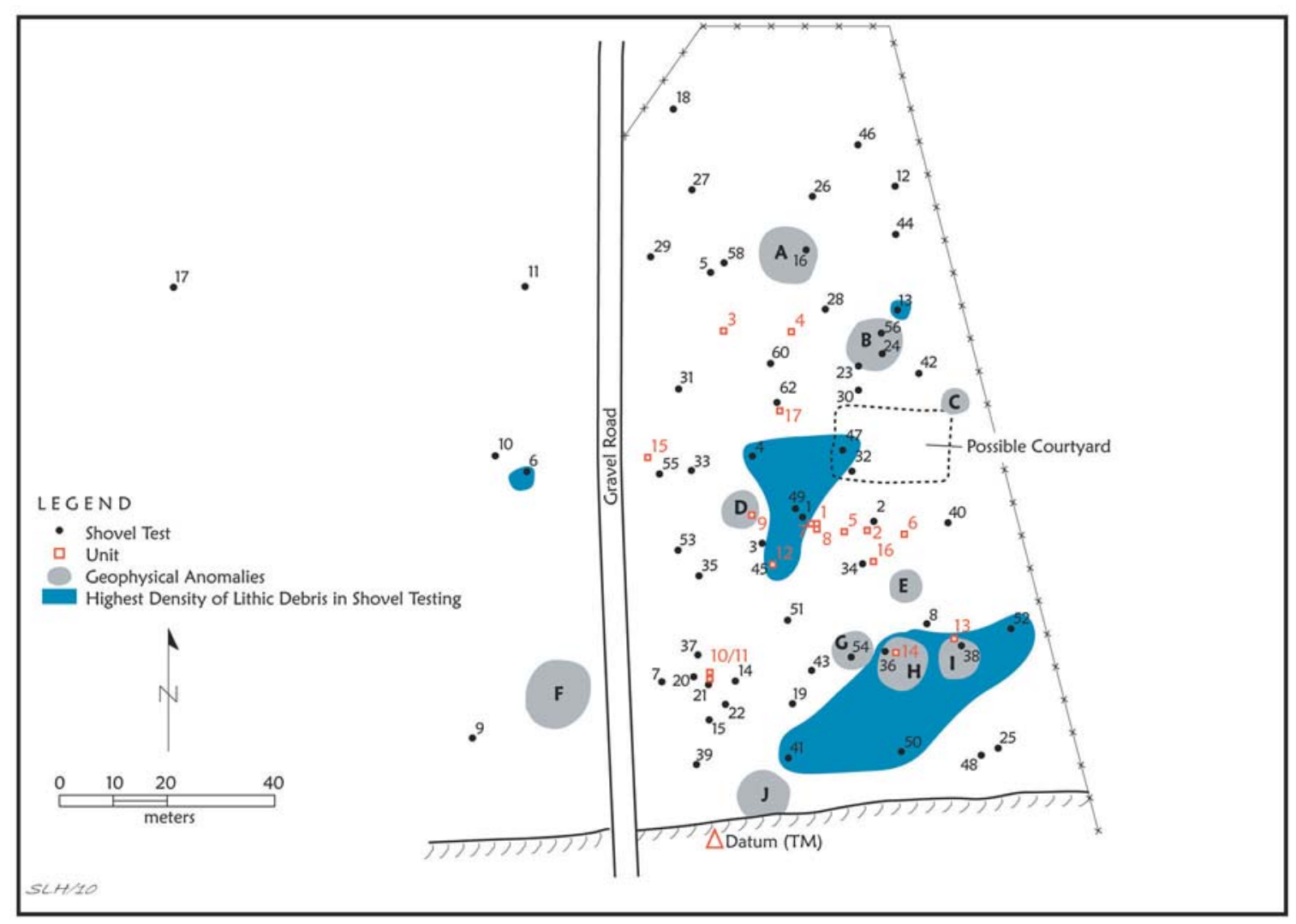

Figure 7. Highest densities of lithic debris in shovel testing.

Caddo Archeology Journal

- 111 


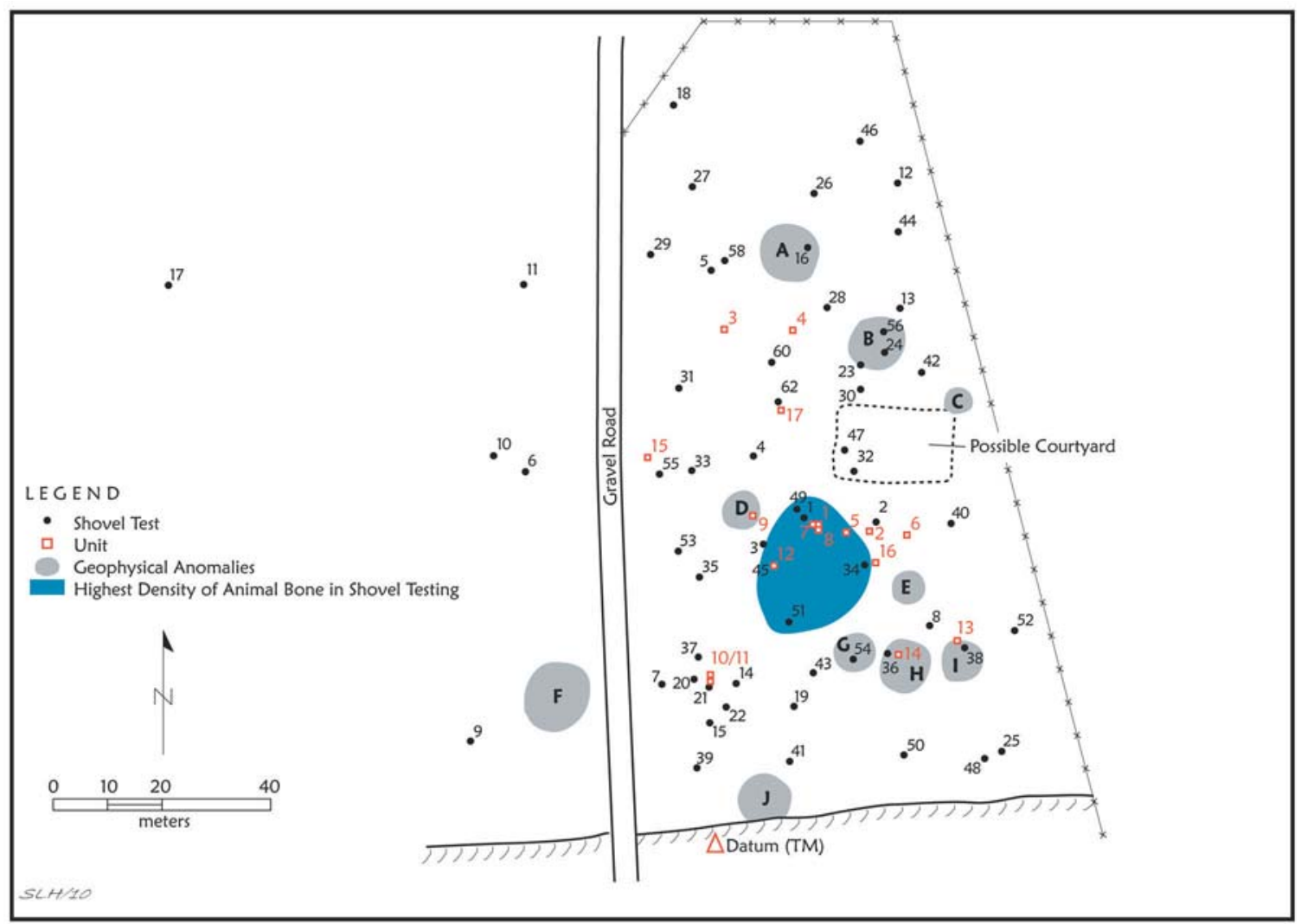

Figure 8. Distribution of the highest density of animal bones in shovel testing.

\section{Conclusions}

Taken together, the archaeological and archaeogeophysical investigations at the J. T. King site suggests that the early $18^{\text {th }}$ century settlement here was comprised of house structure clusters flanking an open area that may be a courtyard or open community area. Possible midden deposits, work areas, and accumulations of trash are situated in the vicinity of, or between, geophysical structural anomalies: the concentrations of sherds and animal bones in one main area suggests that there was one principal area of trash accumulation used by the entire community. Comparable patterns of settlement organization appear to be present in archaeological deposits at other investigated sites in the Angelina River basin in East Texas that date from the $14^{\text {th }}$ century A.D. to the early $18^{\text {th }}$ century A.D., including the Walter Bell site (41SB50) (Jelks 1965:Figure 20), Tallow Grove (41NA231) and Beech Ridge (41NA242) (Perttula 2008:232-273), and the Deshazo site (41NA27) (Story 1982, 1995:Figure 82).

\section{Acknowledgements}

We want to thank the National Park Service, National Trails Intermountain Region, for the opportunity to conduct the work upon which this article is based, especially Michael Romero Taylor and Sharon Brown. We acknowledge the landowner, Wes Wisener, for granting permission to conduct this work on his land. The help of Dr. Tom Middlebrook was indispensable. Finally, Sandra Hannum prepared the distribution maps that are used in this article. 


\section{References Cited}

Good, C. E.

1982 Analysis of Structures, Burials, and Other Cultural Features. In The Deshazo Site, Nacogdoches County, Texas, Volume 1, edited by D. A. Story, pp. 51-110. Texas Antiquities Permit Series 7. Texas Antiquities Committee, Austin.

Jelks, E. B.

1965 The Archaeology of McGee Bend Reservoir, Texas. Ph.D. dissertation, Department of Anthropology, The University of Texas at Austin.

Middlebrook, T.

2007 A Survey of Historic Caddo Sites in Nacogdoches County. Journal of Northeast Texas Archaeology 26:99-115.

Perttula, T. K. (editor)

2008 Lake Naconiche Archeology, Nacogdoches County, Texas: Results of the Data Recovery Excavations at Five Prehistoric Archeological Sites. 2 Vols. Report of Investigations No. 60. Archeological \& Environmental Consultants, LLC, Austin.

Perttula, T. K., B. Nelson, and M. Walters

2011a Archeological Survey Investigations to Identify 17th-early $19^{\text {th }}$ Century Caddo Sites along El Camino Real de los Tejas National Historic Trail in East Texas. Archeological \& Environmental Consultants, LLC, Austin.

2011b Archaeological Sites along King Creek in Western Nacogdoches County, in East Texas. Journal of Northeast Texas Archaeology 34: 69-77.

Story, D. A. (editor)

1982 The Deshazo Site, Nacogdoches County, Texas, Volume 1. Texas Antiquities Permit Series 7. Texas Antiquities Committee, Austin.

1995 The Deshazo Site, Nacogdoches County, Texas, Volume2. Studies in Archeology 21. Texas Archeological Research Laboratory, The University of Texas at Austin.

Walker, C. P. and T. K. Perttula

2010 Archaeogeophysical Investigations at an Eighteenth-Century Caddo Site in Nacogdoches County, Texas. Southeastern Archaeology 29(2):310-322.

2011 Archaeogeophysical and Archaeological Investigations at a Historic Caddo Site along El Camino Real de los Tejas: The J. T. King site (41NA15) in Nacogdoches County, Texas. Archaeo-Geophysical Associates, LLC and Archeological \& Environmental Consultants, LLC, Austin.

Walker, C. P., T. K. Perttula, T. Middlebrook, B. Nelson, and M. Walters

2009 Volunteer Archaeogeophysical Investigations at an Historic Caddo Indian Site in East Texas. ISAP News (20):7-8. 